\title{
THE ROLE OF E-MAIL IN AN INDUSTRIAL DISPUTE
}

\author{
Nava Pliskin * \& Celia T. Romm** \\ * Deparment of Industrial Enginecring and Management, \\ Ben-Gurion University of the Negev, \\ Beer-Sheva, Israel. \\ Fax: (07)280776, Tel: (07)472203. \\ E-mail address: npliskin@black.bgu.ac.il \\ * *Department of Management. \\ University of Wollongong. \\ Wollongong, NSW, Australia. \\ Fax:: (042) 272785, Tel: (042)214046. \\ E-mail address: c.romm@uow.cdu.au
}

\begin{abstract}
The purpose of this paper is to show, based on a case study. how electronic communication networks have affected the process of a large scale industrial dispute. The case study describes a two-and-a-half month long surike of academic staft members at all universities in Israel. During the strike, electronic mail (e-mail) was used as a major means of communication between faculty members. Sources of dala for this paper were mass-media reports, including repurts from national radio, TV, and newspapers, participant observations, and messages that flowed on the c-mailing list throughoul the lengthy strike. Analysis of the data from the various sources suggests that the e-mailing list was instrumental in enabling the strikers to succeed in what was presumed to be a horeless battle. The paper is concluded with a discussion of the lessons to be drawn from this case for e-mail rescarch and practice
\end{abstract}

\section{THEORETICAL BACKGROUND}

E-mail is a communication medium which can facilitate exchange of addressed messages between computers via electronic transmission paths (Culnan and Markus, 1987; Gaukroger, 1988). Much of the early research on e-mail focused on its diffusion process. The vast majority of the early papers tended to look at the diffusion process of e-mail as a dependent variable, i.e., as a process that is caused by other social phenomena. Within this perspective, early papers tended to attribute successful diffusion projects to technological aspects (Pliskin, 1989; Pliskin, Ball, and Curley, 1989). It is only in the last five years that non-technological explanations, individual and collective, have started to receive attention.

Lynne Markus, in a recent paper on e-mail use (1994), contrasts individual and collective level explanations for e-mail diffusion (or lack of it). Among the individual-level obstacles for diffusion she lists: fear of change, lack of user involvement, lack of motivation, and difficulties related to user cognitive style. Among the collectivelevel obstacles to diffusion she mentions: avoidance of e-mail adoption due to cultural reasons, situational factors, and structural pressures from other organisational members. Markus concludes that individual-level considerations are not enough to explain why members of organisations choose e-mail for some of their communication tasks. She strongly recommends that future research should explore the collective nature of email use.

It is only in recent years that the collective nature of e-mail use has begun to be researched extensively. In a review by Rob Kling (1995) he singles out several studies as the major contributions in this area. The first among these studies is Sproull and Kiesler's book, "Connections" (1991), in which they set the stage for examining e-mail in organisations. These authors were among the first to argue that e-mail has social features that distinguish it from other communication technologies, i.e., it enables people who are at the periphery of organisations to become more visible, and facilitates communication between people at the bottom of the organisational hierarchy and those at the top. In these ways e-mail can actually have a "democratising" effect on organisations.

A related pioneering work on the collective-level aspects of e-mail was undertaken by Finholt and Sproull (1990). In this research they investigated how e-mail can facilitate group decision making and bring about group unity and cohesion. Rice's series of investigations (Rice, 1987; Rice, 1990; Rice and Aydin, 1991; Rice, 1992; Rice, 1993) have also been important in demonstrating the effect of networks on group behaviour in the workplace, with particular emphasis on how membership in networks affects members' attitudes about the new technology, and promote group innovation.

The purpose of our paper is to build on the growing body of research on the collective-level aspects of e-mail by exploring the effect of e-mail on the successful outcome of an industrial dispute. The main focus of the paper is on the impact that an e-mail list, established by a group of strikers to support their struggle, had on the process and outcome of the strike.

The qualitative methodology used in this study (detailed in the next section) was case analysis. The case study (in Section 3) describes a two-and-a half months long strike that was the culmination of a much longer struggle 
for improved pay and status of faculty members at all state universities in Israel. The industrial dispute started before the strike and ended only after a two-and-a-half months long period of post-strike negotiations. The final contract between the union and the universities was signed about five months after the strike began. The discussion (in Section 4) elaborates on how the e-mailing list, which was established by the academics to support their struggle, enabled them to initiate and manage the simultaneous negotiation processes that were involved in this large scale labour dispute. The discussion suggests that, in retrospect, e-mail can be seen as an important "weapon" which enabled the strikers to maintain their unity in the face of extreme pressures from all directions. The discussion is concluded with suggestion for directions for future research and implications for IS policy makers and practitioners.

\section{DATA COLLECTION}

Data for this study was collected by the authors. One of the authors, a faculty member at Ben-Gurion University of the Negev, was able to gain access to materials that would otherwise be inaccessible. Sources for data included: the mass media, participant observations, written communication distributed by the universities and the unions, and e-mail messages which appeared on the various e-mail lists established by the strikers. The different sources of data were complementary and mutually supportive. Both authors were involved in all data analysis activities and attempted to reach agreement whenever findings or their interpretation of the findings were in dispute.

\section{Mass media}

The media was highly involved in the strike. Both sides to the dispute tried to harness the media to strengthen their bargaining position. The authors collected many newspaper reports and followed radio and television coverage, including interviews with strike activists, students, and other involved figures.

\section{Participant observations}

One of the authors participated in the strike. In her capacity as a striker she attended all faculty meetings called by the local union and received all memorandums distributed before and after such meetings. Impressions from those observations were shared with the other author soon after the observation took place.

\section{E-mail messages}

Electronic communication emerged early during the strike in the form of several local e-mailing lists. Faculty members were encouraged by local unions to subscribe to ACADEMIA, an e-mail-based user group which was opened to all interested faculty members. ACADEMIA provided a forum for exchange of ideas and distribution of information from strike activists. One of the authors subscribed to ACADEMIA, forwarding all messages (over 600 messages were collected and analysed) to the other author. Both authors engaged in textual analysis of all electronic messages exchanged on the network.

\section{CASE STUDY}

\section{General Background}

In early January 1994, shortly before the end of the Fall semester, faculty members in all seven Israeli universities initiated a strike, suspending all work related to the teaching of 90,000 students, including: lectures, labs, exams, grading, and counselling. The strike was declared by the Co-ordinating Council of Faculty Unions (co-ordinating council, hereinafter) which included representatives from each of the seven local unions. Other parties who were involved in the dispute were The Treasury Ministry, The Committee of University Presidents, and The Planning and Grants/Budgeting Committee of the Council for Higher Education (Singer, 1994).

The main reason for the strike was that salaries in the academic sector eroded continually over the decade which preceded the strike to well below other salaries of researchers in the public sector. This had been the situation despite many previous faculty strikes, which were relatively brief and did not yield satisfactory results. A two-week long strike, declared by the co-ordinating council at the end of 1992, led The Committee of University Presidents to recognise that the entire Israeli higher education system was at stake and to nominate 
an objective commission charged with in-depth investigation of faculty reward structure. The commission's report, filed toward the end of 1993, recognised the need to increase salaries by $30 \%$. The commission also recommended tactics for executing this policy, including linking faculty salaries to nation-wide salary index (to prevent salary erosion in the future) and funding raises by reduction of sabbatical privileges. Both sides, however, rejected parts of the report. The treasury was unwilling to go beyond the $20 \%$ raise offered to others in the public sector and refused to link faculty salary to any index. The co-ordinating council demanded more than $80 \%$ increase and objected to any reduction in sabbatical benefits.

All parties involved in the strike did not expect it to be long. Based on many previous instances in which Israeli academics went on short strikes that did not yield any substantial results, the expectation was that this strike too will be short and ineffectual. Consequently, the fact that the strike lasted 75 days and resulted in a $70 \%$ increase to academics' salaries was a surprise to all. The remainder of this section will present the events of the strike as they unfolded.

The remainder of this section will present the events of the strike as they unfolded chronologically. Sources of data for this discussion included the mass media, e-mail flow, and participant observations. Events are presented in sequence following the three major stages of the strike, initiation, escalation, and resolution.

\section{Events of the Strike}

\section{Initiation}

The media's involvement in the strike started on its first days. Both sides to the dispute used the media to gain public support for their position. Each side posted announcements in newspapers and gave interviews that were broadcast on radio and television. The heavy coverage by the media also included daily reports on the strike, with headlines that included a day count since the strike started. Newspapers also carried editorials and letters to the editor from striking faculty members, students, and interested members of the general public.

The public was exposed to frequent statements issued by the treasury ministry, attempting to prove that the cause of the strikers was unjustified and that faculty members were being irrational, irresponsible, and impossible to negotiate with. For instance, in order to show that faculty salaries were fair, the media was informed that faculty members only teach eight hours per week.

The strikers were also involved in the war of words. In the early stages of the strike they too devoted resources to combat public opinion. For instance, interviewed faculty members revealed that teaching involves twice as many hours of preparation and grading, and that promotion decisions are mainly based on publication output, rather than teaching, forcing faculty members to invest much more than eight hours per week in their work. The co-ordinating council took part in the public debate by providing the media with tables, underlining the gap between faculty salaries and salaries of other researchers in the public and private sector.

Even though the strike received much attention from the media, the public was not exposed to the information that flowed internally among faculty members within the Israeli campuses. Shortly after the strike started, an email-based user group entitled ACADEMIA was created. In addition to word of mouth and announcements during faculty meetings, the existence of ACADEMIA became known to the strikers electronically. It was advertised through e-mailing lists established by the local unions on each campus, even before its creation.

The ACADEMIA e-mailing list distributed messages from the co-ordinating council and messages which originated from ACADEMIA subscribers. Local mailing lists distributed messages from their own constituency, from the local union, from the Tel-Aviv union, and from the co-ordinating council. Thus, while ACADEMIA subscribers were exposed to more strike-related e-mail traffic than non-ACADEMIA subscribers, it is safe to assume that non-ACADEMIA subscribers who subscribed to local e-mailing lists at their campuses were exposed to the major messages distributed by the co-ordinating council as well as to the Tel-Aviv bulletins.

It should be noted that even though information from the co-ordinating council (as opposed to inaccurate information published by the media), was available to strikers almost in real time, initially, the local e-mailing lists and ACADEMIA were perceived by union activists as primarily a one sided channel of information. This was reflected in the fact that in the messages transmitted during the first weeks of the strike (all of which were from the co-ordinating council) there were no requests for strikers' input, suggestions, or opinions. It was only later, as the strike lingered, that both the co-ordinating council and the strikers realised that the network could be used for many purposes other than top down dissemination of information.

Following is a typical example of the early "report type", one sided messages issued by the co-ordinating council.. 
Dear Comrades,

Yesterday was too tiring ( 13 hours devoted to the strike) for me to sit down and report. Here is a brief summary for your information. Discussions in our "Bunker" are getting into swing. We are becoming organised. Help is welcome at any time of the day. A circular letter to all members of the union from us has been dispatched. It includes "real data" about our salaries, as opposed to the false data disseminated by the other side. Make as much use of it as possible. We are trying to complete the "network of internal communications" within our university and other universities as well- if you know of isolated faculties, universities etc. let us know and eventually suggest people who could be used as "contacts" for them.

\section{Escalation}

Within the first month of the strike it became apparent that neither party to the dispute was likely to back down easily. The escalation of the struggle involved high-level figures including: the prime minister, the minister of education, the minister of finance, and many members of the parliament. The prime minister spoke against the strikers, backing the minister of finance who threatened to close the universities. Parliament members tried to bring forth a compromise solution but were unsuccessful. As the strike continued, the student unions became increasingly vocal about the strike and its grave implications to them. Their protest demonstrations, some of which were quite violent, conveyed the message that they were the innocent victims of the strike. In addition to requesting an end to the strike, students also demanded passing grades for Fall semester subjects.

In confronting their opponents, the strikers turned to a consulting company whose speciality was public relations. The firm was retained by the co-ordinating council throughout the strike, advising members of the Council on ways of dealing with the situation.

The faculty meetings, which were called by local unions every other week to report on (lack of) progress, were exposed to the public eye through the media. In every meeting, the local representative of the co-ordinating council asked for a vote of confidence, which was always unanimously forthcoming.

As the struggle was escalating, the use of the e-mailing lists evolved and became more sophisticated. Many of the informative messages from the union were now written immediately after late- night negotiations and were available to strikers early in the morning. This helped strikers cope with attempts by the other side to break their unity by distributing false information. Messages from the union now reflected the fact that the list had transformed from a one sided channel of communication to a multi-channel forum of discussion and debate. Following is a message transmitted by the co-ordinating council at this stage for the purpose of responding to the on-going debate on strategy.

\section{1st day}

Friends.

People are sending us interesting and important ideas for things to do. I will mention two ideas that seem worth pursuing. First, the labour party is holding a meeting next week in Tel-Aviv. All the party ministers will be there. We should stage a demonstration in front of the building. Our experts on demonstrations please pick up the idea and go with it. Second, we might consider organising an "altemative University system". Similar to what the physicians did in their strike (they established an alternative privately financed hospital system). Does anyone know how to do it? We need volunteers to develop this.

Another use of e-mail by the unions was to minimise the effect of tactics employed by the other side in order to break the strike. For instance, strikers were electronically notified of arrangements made by the union with the banks to provide loans to faculty members whose salaries were withheld by the universities. Following is an example of such messages:

45th day

Dear Comrades.

It seems that the top political figures are in panic. Let's stand strong and united. On another matter. I just returned from my bank. They have special loans for the faculty members that are on strike. Their loan is for 12 months with a fixed interest of $13 \%$. Return of the loan starts two months from receipt. In 
addition you can increase your credit line from $\$ 3000$ to $\$ 6000$ with an interest of $15 \%$. If necessary, our representative can sit with you and help those with problems. Keep the faith.

As a solution to the dispute did not seem eminent, the use of e-mail as an important communication vehicle spilled over to non- Israeli institutions. The e-mailing lists were now being used to recruit support for the strike from academics around the world. The strikers believed that introducing international pressures would have an effect on the government, which was at the time very sensitive to world public opinion due to the peace process. A long message, entitled "Crisis in Israeli Higher Education" was put together, detailing the state of academia in Israel in general, including salaries and faculty-to-student ratios.

ACADEMIA subscribers were asked to share the "Crisis in Israeli Higher Education" file with their colleagues overseas and to encourage them to respond. Indeed, academics from all over the world were moved to write supporting letters, addressing them, as requested by the Council, to leading politicians in Israel, including the Prime Minister. Following are two examples of these supporting letters as they appeared on ACADEMIA.

\section{2 nd day}

Is there a way that friends here in the US can actively help you? I'm willing. as I am sure many of my colleagues here are, to do what we can to help. Reading the messages on the Internet help us understand, but they don't directly help the cause. Peter. US

46th day

A copy of a letter sent directly to the Israeli Prime Minister

Having taught as a visiting professor of Comparative Literature at the Hebrew University of Jerusalem and at Tel Aviv university, I am extremely dismayed by the erosion of higher education in Israel. I feel that the issue reaches beyond the question of Israeli cultural identity. It involves, indeed, the future of a whole region of the world where peace and those human values necessary to sustain peace must come to prevail if the rest of the world is to address the new imperatives of global politics that are emerging after the Cold war. I have learnt from experience that Israeli universities are centres of intellectual excellence and of enlightened thinking that make them invaluable to a larger international community. It is in the perspective of this larger community that a new generation of leaders as world citizens must be formed if Israel is to endure in years and centuries to come. I believe that the Israeli government should listen carefully to the concerns of scholars throughout the world who support the cause of higher education in Israel. (name) University of Washington.

It is important to note that as the dispute escalated and as strikers developed confidence in the e-mailing list, messages from strikers (as opposed to activists) became prevalent. The e-mailing lists were used by nonactivists to discuss objectives of the struggle, methods for achieving these objectives, and ways of increasing the effectiveness of the strike. In particular, the issues of securing supportive public opinion nationally and internationally and the means toward this goal were discussed in much detail. Also important in the public debate were discussions of negotiation strategy, i.e., issues that should or should not be compromised on. Following are three messages which reflect the heated public debate on e-mail on how the struggle should be managed.

\section{4th day}

It was reported on TV this morning that WE are ready to settle for $40 \%$ over 4 years. To those of you who are not familiar with finances (I am just an amateur myself), let me explain the actual meaning of this offer. Consider Mr. $X$ who is right now having our salary. Mr. X will not get any real raise over the next 4 years. His salary will be monthly updated according to the rate of inflation which will actually give him an addition to his salary of over $40 \%$. In fact settling for $40 \%$ over a period of 4 years actually means giving up some of the money that we would have gained anyway. This is totally ludicrous!!! 
44th day

Why is $40 \%$ in three years plus indexing and without giving up any benefits that we now have so bad? Perhaps a "salami" (step by step) approach is better? In 1997 we'll be able to renew the battle. Somebody really thinks that we will indeed get a $102 \%$ raise right now? Whoever thinks so, must be nuts!!

46th day

I wish to point out that the calculations of the "average salary of academics in four years" is highly inaccurate. When you take into account seniority, the figures are much higher than the $\$ 1200$ quoted by the member of the Council. My colleagues' suggestions that we should compromise are not as ridiculous as the Council is trying to make us think. In fact, the last few letters expresses a widespread unease that many of us apparently feel about the way in which our leaders (mis)lead us.

\section{Resolution}

During the last phase of the strike, it became clear to all parties involved that if the dispute was not resolved within days, the school year would be lost. The co-ordinating council persisted in telling the public that, for the first time in the history of the state of Israel, one semester, or even a full academic year is about to be lost. The uncertainty surrounding the academic school year was of major concern to the students and their families, who together constituted a large segment of the Israeli public.

By now, students became more aggressive, attempting to disrupt non-teaching activities that the academics continued despite the strike. Student demonstrations were primarily aimed at blocking the entrances to campuses in order to stop work on research projects. For instance, several professors received threatening phone calls, and there were attempts by students to interrupt faculty meetings.

Students were not the only group trying to interrupt non-teaching activities of faculty members. When the ministry of finance announced that funds will no longer be transferred to the universities, forcing the universities to close down, non- academic employees were affected as well. Their unions which at the beginning of the strike were supportive of the academics, were alarmed about the situation as it meant loss of income to their members. This caused additional pressure on the strikers as well as on the government.

When the Israeli president offered help, summoning the parties to the dispute in an effort to bridge the gap between them, he was asked by the prime minister to back off. From this point on, however, not only the strikers but also the government felt under pressure to produce results. With the president's involvement and the rift between the prime minister and the president, the dispute was developing into a political crisis that called for a much more serious approach by the government.

Another source of pressure to end the strike was related to the massacre in Hebron and the fact that, for a while, the peace process was halted. It made the strikers realise that they were not that important in the general scheme of things. It made the government realise that, following the Hebron events, the futile struggle with the academics was an embarrassment and that to please public opinion locally and internationally the strike had to end. The Hebron Massacre has changed the two sides' perspective. The strikers realised that they had to compromise because public opinion was moving away from them to more important issues. The government realised that with public opinion in the US going against Israel, and with the peace process being threatened, the conflict with the academics, who by virtue of their profession have better contacts in the US than any other employee group in the country, had to be resolved immediately.

Following are a few messages which appeared on ACADEMIA during the last days before negotiations leading to the resolution of the crisis were resumed. The messages reflect the mounting pressures on the Council from the members of the union, the various other stake holders (students, administrative staff) and other local and international interested parties.

\section{7th day}

Dear comrades.

The weeks before the holidays will be decisive, since it is clear to everybody that after the holidays, it will be too late to salvage the academic year. We need now more patience and resilience. On the public front colleagues have complained that the strike disappeared from the news in the course of the week. It is likely that in the wake of the Hebron tragedy, it will be even less in the public awareness. We shouldn't 
worry too much about this, however. In all likelihood, the students and the media will realise the gravity of what is at stake (the fate of the academic year) and then suddenly the subject will return to the media in full force. Finally, about our network.

54th day

Here is an interesting question raised in my department. Are we working or are we not? For sure we are not getting a salary. So the question is are the universities paying our other benefits? For example, I come to work daily. What will happen if on my way to work tomorrow I get involved in a car accident? Is my insurance still paid for? Do the universities continue to pay for our pension funds? Those who pay for medical insurance through the university, should they go and pay personally, or is it taken care of? Is anybody in the union giving any thought to these issues? Is anybody taking care of us?

60th day

I just received a phone call from a concerned colleague. Someone called his home this morning, shouted "death to the professors" and hung up. It is not surprising that some frustrated students should vent their frustration this way. However, coupled with the violent and abusive verbal behaviour of the students who disnupted the TAU senate meeting last week, it may be a cause for concern. There is little we can do to counter such phone calls except, perhaps to monitor their frequency. Thus, I am volunteering to keep track. Please let me know if you receive any abusive calls or if someone you know receives one.

6 Ist day

It seems to me that our PM, several members of his Cabinet, many members of the Parliament and top administrators in the Finance ministry are very much against any reasonable settlement with us- with no real, clear-cut reason. While their explanations for their position make no sense, their public announcements suggest a strong and unexplained, emotionally based, and absolute, aversion towards negotiating with us. We need a different approach to these people, one based on a psychological analysis of their personality. Such analysis may produce better results than the total deadlock that we are facing now

As the above messages suggest, events at this stage of the strike created an atmosphere of "now or never", with all parties realising that time was getting short and was not on any body's side. The two sides were thus open to suggestions and receptive to innovative approaches. With this background, two non- activists faculty members came up with a proposal that for the first time was acceptable to both sides. Based on this proposal, an agreement which brought the strike to an end was drafted.

During the final stages of the strike, the e-mailing lists served several important purposes. The most important role was probably in boosting morale. Numerous messages transmitted by the co-ordinating council were aimed at promoting and maintaining faculty solidarity and support. Many non-activists used the e- mailing lists to distribute messages that not only supported the union but also encouraged fellow strikers to keep the faith and to believe that time is on their side and that the other side will not be able to take a very long strike. Following is a typical message from the Council, incorporating information on the progress of the negotiations with comments that are intended to boost morale.

71 st day

Yesterday and today's round of negotiations was possibly the longest in the history of the present dispute. From $3.30 \mathrm{pm}$ to $5.00 \mathrm{am}$ this morning we were sitting together. All these long hours were dedicated to the discussion of the criteria that will entitle faculty members to receive the special addition to their salary. The other side wants criteria that will accomplish two things at once: differentiate clearly between academics and other groups, differentiate among the academics themselves. We, on the other hand, contend that the present task is only to define how we differ from others. For we see the special addition as a way for the govemment to give us the $60 \%$ increase to our salary without causing the domino effect the government is so concerned about. We believe that differentiating BETWEEN academics is something that should be done by academics and at this point should not be discussed at all. I know that many of you are tired of this long strike, but hold on. Keep the faith. Justice is on our side and we will win this war. We have to. 
The e-mailing lists have become an essential life-line, gaining an unprecedented level of user awareness and appreciation. Many messages were devoted to describing how important the network has become to users. When employers threatened to cut off the electricity, the e-mailing lists were used to consider alternative means of communication. Messages exchanged at that time reflected an awareness that interruption of e-mail services could be a fatal blow to the strikers' ability to keep fighting. Following are several short messages, reflecting strikers' dependence on e-mail and the important role they felt e-mail was playing in the strike. Note that the first letter is being written in the dark, by an activist who feels that sharing his views with fellow strikers even under these extreme conditions is essential.

\section{5th day}

Fresh news: today at 12.00 the administration workers shut down the electricity- no electricity!! I am writing from the computation centre where we have a bit of light, but most of the other places are dark. I talked to some students a few hours ago and they are organising some demonstrations here too. They burned some tires earlier... The academics are amazed and lots of TV and radio people are here too. There are many arguments in the corridors between administrative staff and academics. At least we too (at BGU) got some action now. Bye for now. I gotta get back to the centre of events.

\section{1 st day}

It looks as if the universities will be totally closed soon. With e-mail not available as a means of communication, we have to establish alternative ways of communication with our colleagues. Stay tuned for information on emergency arrangements for the union operation (new office, phone, fax numbers etc.) At this point, it is ABSOLUTELY CRUCIAL not to rest during the coming holidays but to conduct a well concerted and clever PR campaign to take full advantage of the irresponsible conduct of the negotiations which led to the present deadlock. They (the other side) are fully responsible for not allowing an agreement that was on the brink of being achieved.

\section{1 st day}

The universities will be closed this weekend and as a result most of the computers will shut down. Accordingly, we must establish a communication procedure that is based on home phones. Please start a communication chain with five members at the top for each faculty/school and then one or two members for each department. Please start establishing this chain as soon as possible. Keep the faith and stay tuned for more information during the day.

As pressure from all directions to stop the strike mounted, the e-mailing lists were increasingly used to discuss the leadership of activists. This included support for leaders, on the one hand, and complaints about lack of progress because leaders were not doing enough or were not doing the right thing, on the other hand. Some emailing list subscribers complained that the struggle was not managed well and even demanded a change of leadership. This culminated in a proposal to conduct a referendum among faculty members in order to resolve issues of direction and leadership. The referendum was heatedly debated and finally rejected by the majority of strikers. During this electronic exchange, messages of e-mail included numerous expressions of support for the strike leaders but also a significant number of vicious personal attacks on leaders and their supporters.

One implication of the leadership debate was that some subscribers, disgusted by the language used over the network, withdrew from the e-mailing list. This, in turn, led to a discussion of whether the organisers of the list should screen messages and prevent "unacceptable" messages from reaching the whole subscriber group. The debate was still going on when the strike ended. After the strike ended, however, ACADEMIA was restructured. Based on lessons from the message flow during the strike, a limited form of censorship was instituted, with managers of the list screening messages that "were not of interest to the group".

\section{DISCUSSION AND CONCLUSIONS}

The description of the three-phased history of the strike in the previous sections was seems to suggest that email played an important role in shaping the events and bringing forth what was hailed by observers as the greatest industrial relations victory in Israeli academia's history.

When we compare the events of the 1994 Israeli academics' strike to previous similar Israeli academics' strikes, it becomes apparent that it was characterised by two aspects that made it unique. First, in contrast to previous 
strikes which were short and ineffective, this one was very long and highly successful in terms of its outcome for the strikers. The second aspect that made this strike unique was the fact that for the first time e-mail was used as the major communication media between strikers.

Is there a link between the two aspects? Can we claim, on the basis of the data provided here, that e-mail made the strike so successful? Although it is a tempting possibility, we believe that the data that we have presented here cannot substantiate such a claim. There are, in fact, several other possible explanations to the unprecedented achievements of this strike. These list of possible explanations include: the excellent negotiation skills of the union leaders, the wide support from members of the public locally and intemationally, Israeli internal politics (the conflict between the prime minister and the president), and even the tragic events of the Hebrew massacre. All of these put pressure on the government to close the gap between its initial position and the strikers'.

And, yet, it is our claim that e-mail's role in shaping the strike's events was crucial. In fact, based on the data that was presented in the previous sections, it appears that e-mail played several important roles, including:

\section{Contribution to Unity within the strikers' group}

The first and most important role that e-mail played in this case was in helping the strikers maintain their unity in the face of pressures from all directions. E-mail was the means through which strikers boosted each other's morale, aired differences, exchanged jokes about their opponents, and eventually reached agreements on issues that were initially in dispute. E-mail was also the means through which strikers offered practical help to members in need and the vehicle through which they consolidated their support of their leadership. The unity that e-mail helped maintain made it possible for the strikers to keep on fighting until the group of stake holders became too large to ignore by the employers and the government.

\section{Facilitation of Communication between strikers and their leaders}

The role that e-mail seemed to have played in this case is that of a mechanism which closed the communication gap between the constituents and their representative negotiators. It facilitated a high level and quality of communication throughout the dispute, enabling the constituents to debate and argue and yet consistently provide their representatives with a united front that they could work from. Thanks to e-mail, the risk of negotiators becoming "separate" from their constituents was minimised. Constituents remained united as a group and were consequently able to maintain their support of the negotiators. In that sense, e-mail helped create an illusion of closeness between the constituents and their representatives. This illusion allowed views that were offensive and even threatening to the negotiators (particularly, had they been expressed face to face), to be openly exchanged on e-mail. These included detailed scrutiny of the negotiators' bargaining behaviour and even questioning of the overall legitimacy of their mandate.

\section{Provision of feedback on the negotiation process.}

E-mail served as a continuing source of input to the negotiating team on acceptable and unacceptable strategies for resolving the dispute. This role has changed throughout the dispute. In the early stages, the major contribution of e-mail was in debating and then initiating the international support campaign. In later stages messages transmitted on e-mail alerted the negotiating team to solutions that were unacceptable and solutions that were acceptable. For example, the numerous messages from constituents calling for compromise on the last days of the strike may have helped the negotiators agree on the principle of criteria for the "special salary increase" to which they were vehemently opposed at the beginning of the strike.

Despite the fact that our case study took place in a specific and rather unique time and place, it has general implications that can apply to much broader contexts.

The first implication has to do with the role of e-mail as a contributor to group unity and cohesion. The process by which groups gain a sense of unity and cohesion is well-documented in the organisational behaviour literature in which several models of group development have been proposed (Tuckman, 1965; Gersick, 1989 , 1990). Our research suggests that virtual communities, such as the group of strikers in our case, maly reach similar levels on unity and cohesion thorough e-mail. Future research may explore the degree to which existing models of group development do indeed apply to virtual communities and help identify further the unique patterns that characterise virtual communities as groups.

The second implication from this research relates to e-mail's political potential. Past research has demonstrated the importance of charging mechanisms to regulate e-mail use (Pliskin \& Romm. 1990). For instance, a liberal 
charging scheme that rewards new users for using e-mail might increase diffusion. The data from this study suggests that political considerations could affect diffusion as well. In an environment where employees are in conflict with management, e-mail's diffusion can be a result of emplyees' desire to use the new technology as a weapon against management. It remains for further research to explore the ways that e-mail can indeed be put to political uses within and between organisations.

Finally, the data from this research raises some intriguing ethical dilemmas for IS researchers and practitioners. As indicated in the case, e-mail can be used by employees for purposes other than the ones intended by management. Indeed, it can be used as a vehicle for staging a revolt against the very people who establish it, whether they are members of management or the leaders of a striking union. What should be the role of IS practitioners once e-mail is used as a political tool by either side? Should IS practitioners facilitate the regulation of e-mail as was the case here when censorship was introduced to ACADEMIA toward the end of the strike? Should IS practitioners advise managers against introducing e-mail to an organisation that has particularly volatile industrial relations? Should IS practitioners side with management when employees decide to sabotage e-mail as part of an industrial dispute? All of these are ethical dilemmas that will have to be addressed by future research on the use of e-mail within and between organisations.

\section{REFERENCES}

Culnan, M. J. and Markus, M. L., (1987), Information Technologies: Electronic Media and Interorganizational Communication, In F. M. Jablin, L. L. Putnam, K. H. Roberts, and L. W. Porter (Eds.), Handbook of Organisational Communication: An Interdisciplinary Perspective, 420-443, Newbury Park, CA: Sage Publications.

Finholt, T. and Sproull, S. (1990) Electronic Groups at Work, Organization Science, vol. 1, no. 1, pp. 41-64. Gaukroger, J., (1988), Information Technology in the Office, Mc-Graw Hill Book Company, London.

Gersick, C. J. K., (1988), Time and Transition in Work Teams: Toward a New Model of Group Development , Academy of Management Journal, 31, 1, 9-41.

Gersick, C. J. K., (1989), Marking Time: Predictable Transitions in Task Groups , Academy of Management Journal, 32, 2, 274-309.

Kling, R., (1995), Social Relationships in Electronic Forums: Hangouts, Salons, Workplaces and Communities, Lead Article for Section IV of Computerization and Controversy: Value Conflicts and Social Choices, by R. Kling (ed.), Academic Press, San Diego (Forthcoming).

Markus, M. L., (1994), Electronic Mail as a Medium of Managerial Choice, Organization Science, Vol. 5 , No. 4., pp. 502-527.

Pliskin, N., (1989), Interacting with Electronic Mail can be a Dream or a Nightmare: a User's Point of View, Interacting with Computers, Vol. 1, No 3: 259-272.

Pliskin, N., Ball, L. D., and Curley, K. F., (1989), Impediments to Proliferation of Electronic Mail: A Study from the Users' Perspective, Human Systems Management, Vol. 8, No. 3: 233-241.

Pliskin, N. and Romm, T., (1990), Design of Charging Mechanisms According to the Interaction between Information Technology Type and Diffusion Life cycle Phase, Database, Vol. 21, No. 3: 34-40.

Rice, R. E., (1987), Computer-Mediated Communication and Organizational Innovation, Journal of Communication, vol. 37, no. 4, pp. 65-94.

Rice, R. E., (1990), Individual and Network Influences on the Adoption and Perceived Outcomes of Electronic Messaging, Social Networks, vol. 12, pp. 27-55.

Rice, R. E., and Aydin, C., (1991), Attitudes toward New Organizational Technology: Network Proximity as a Mechanism for Social Information Processing , Administrative Science Quarterly, vol. 36, pp. 219-244.

Rice. R. E., (1992), Contexts of Research on Organizational Computer-Mediated Communication, in M. Lea (ed.) Contexts of Computer Mediated Communication, Harvester Wheatsheaf, England, pp. 113-144.

Rice, R. E., (1993), Using Network Concepts to Clarify Sources and Mechanisms of Social Influence, in W. Richards Jr. and G. Barnett (eds.) Progress in Communication Sciences, vol. 12, Norwood, NJ: ABLEX.

Singer, A., (1994) Faculty Strike in the Israeli Universities, Israel Studies Bulletin, Vol. 9, No. 2, Spring, 16-20.

Sproull, L. and Kiesler, S. (1991) Connections: New Ways of Working in the Network, MIT Press, Cambridge, MA.

Tuckman, B. W., (1965), Developmental Sequences in Small Groups , Psychological Bulletin, June, 384-99. 